Ročník XVII (2015), Číslo 3-4, s. 393-397 / Volume XVII (2015), Issue 3-4, pp. 393-397

(c) Mezinárodní politologický ústav / International Institute of Political Science

DOI: $10.5817 / C E P S R .2015 .34 .393$

\title{
Petr Voda: Jaká je role postkomunismu? Volební geografie České a Rakouské republiky v letech 1990-2013
}

Brno: Centrum pro studium demokracie a kultury, 2015, 244 stran. ISBN 978-807325-369-1

\section{JAKUB LYSEK ${ }^{1}$}

Kniha Petra Vody se snaží odpovědět na otázku, jaký vliv má postkomunistická tradice na utváření prostorových vzorců volebního chování. K tomu slouží analýza parlamentních voleb v České a Rakouské republice, která vychází z teorie štěpících linií. Čtenáři se především dozví, jak rovnoměrně je rozložena volební podpora českých a rakouských stran, a to i v čase. Dále jsou zpracovány mapy stabilní podpory jednotlivých stran, kdy patrně nejatraktivnější je mapa volební podpory populistických stran, které často bývají na okraji zájmu. Jádro knihy pak tvoří vysvětlení rozdílné volební podpory stran v prostoru na základě socioekonomických proměnných jako je např́lklad podíl vysokoškolsky vzdělaných obyvatel, podíl důchodců a podíl rozvedených.

Výběr České a Rakouské republiky je logický. Obě byly v minulosti součástí společného státu a jsou si v mnoha ohledech podobné. A právě komunistická zkušenost jedné z těchto zemí dává př́iležitost zkoumat zajímavé teorie, s nadsázkou řečeno, v téměř laboratorním prostředí. Přesto podobných komparací najdeme jen skrovně a zasloužily by si je i jiné oblasti politické vědy. Na druhou stranu výběr př́padů lze vždy jednoduše zkritizovat, protože lze snadno namítnout, proč autor nezahrnul zemi $\mathrm{X}$ nebo $\mathrm{Y}$, která by jistě byla $\mathrm{Z}$ komparativního hlediska zajímavá. Při rozšíření studie o dalších země, at’ už by se jednalo o Polsko či Slovensko, v opačném zeměpisném směru např́iklad o spolkové země bývalé NDR, by sice došlo k rozšíření "vzorku zemí", ale mohlo by to již být ke škodě samotné knihy. Takový text by se jistě stal komplikovanějším, rozsáhlejším a autor by se musel vyhnout mnoha nástrahám.

\footnotetext{
${ }^{1}$ Katedra politologie a evropských studií, Filozofická fakulta Univerzity Palackého v Olomouci, Křižzovského 12, 77180 Olomouc, Česká republika / Department of Politics and European Studies, Faculty of Arts, Palacký University, Olomouc, Czech Republic. Contact:
} jakub.lysek01@upol.cz. 
Komparaci pouze dvou zemí tak po přečtení knihy naopak vidím jako výhodu, i když se musím přiznat, že jsem původně při prvním letmém zhlédnutí obálky knihy trochu pochyboval o autorově zvoleném postupu.

Volební geografii a volebnímu chování se v českém prostředí věnuje již řada publikací, nedávno např́klad knihy Koho voli V aši sousedé? (Kostelecký et al. 2014) a Geografie výsledkư parlamentnich voleb (Kostelecký et al. 2015) nebo zejména celá řada odborných článků Lukáše Linka. Mohlo by se tak zdát, že další práce na stejné téma již nemá co nového nabídnout, navíc $\mathrm{v}$ době, kdy se výsledky voleb zobrazují online naprríklad v datové sekci Českého rozhlasu. ${ }^{2}$ To platí jen zčásti. Originální je již zmíněná komparace s Rakouskem, ale i fakt, že ačkoliv je kniha ukotvena $\mathrm{v}$ tradičním teoretickém rámci konfliktních linií, kterými je česká (brněnská) politologie snad téměr posedlá, tuto teorii zevrubně popisuje a rozšiřuje o aktuální poznatky. Pro studenty politologie pak bude kniha cenným zdrojem informací, ale i odkazů na další českou i zahraniční literaturu v této oblasti. Jen možná stojí upozornit na malou drobnost. Strana KDU-ČSL ve volebním období 2010-2013 měla zastoupení v Senátu, tudíž není zrovna přesné mluvit rovnou o neparlamentní straně (Voda 2015: 92).

Kniha je vhodně a logicky strukturovaná. Teoretická část, metodologie i analýza jsou navzájem propojené. Text věrně odpovídá nárokům kladeným na akademické práce. To však $\mathrm{v}$ prípadě publikace, která svým tématem má potenciál oslovit i laickou veřejnost, nemusí být vždy výhodou. Některé pasáže totiž působí velmi stroze. Na obranu autora Petra Vody lze ovšem konstatovat, že je obtížné poutavou formou popsat celou řadu téměř identicky vypadajících tabulek a čísel; rovněž interpretace řady po sobě uvedených regresních modelů již může čtenářovu pozornost poněkud otupit. To vše ale $\mathrm{k}$ analýze patří a i z jiných textů si na to akademický čtenár časem zvykne. Bohužel zklamáním může být závěr knihy, kde autor pouze shrnuje a opakuje výsledky analytické části, respektive se opět jedná o popis regresních modelů. Zasazení výsledků do širšího kontextu, resp. jejich interpretace ve vztahu k otázce položené v úvodu knihy, je obsažena pouze v poslední větě knihy, kdy se čtenář dozví, že „postkomunismus nutí strany hledat si svou voličskou základnu, $\mathrm{k}$ čemuž jsou ale nuceny také nové strany v západním kontextu. “ To je ovšem málo, přestože se v knize dočteme spoustu zajímavých poznatků, ze kterých jistě lze vyvodit originální závěry.

Patrně nejdůležitější částí knihy je metodika práce a samotná analýza. Oběma se nyní budu věnovat současně. Standardně pro analýzu volební podpory můžeme využít základní popisné statistiky disperse dat jako směrodatná odchylka či variační koeficient $(\mathrm{VK}), \mathrm{kdy}$ směrodatnou odchylku vydělíme průměrem, což nám zajistí lepší srovnatelnost. Strany, které mají vysoké hodnoty VK, mají logicky vyšší nerovnoměrné rozložení volební podpory, naopak strany s nízkými

\footnotetext{
2 Český rozhlas, dostupné na: http://www.rozhlas.cz/zpravy/data/_zprava/pred-25-lety-jsmepoprve-svobodne-volili-prozkoumejte-vysledky-v-obcich--1498867
} 
hodnotami mají volební výsledky v prostoru rozloženy rovnoměrně. Zajímavé je v tomto př́padě využití Giniho koeficientu, který bere v potaz i počet voličů územních jednotek. Při srovnání hodnot obou koeficientů patrně převažují výhody druhého z nich, protože lépe zachytil známé vlastnosti českých politických stran, kdy jsou voliči KDU-ČSL, TOP09 a liberálních stran $\mathrm{v}$ prostoru nerovnoměrně rozloženi a koncentrováni. Prvotní část práce přinesla zajímavá obecná zjištění, která s pár výjimkami platí pro většinu stran. Pokud podpora (volební zisk) strany roste, klesá i nerovnoměrnost rozložení zisků a podpora se stává méně koncentrovanou. Naopak pokud podpora voličů klesá, roste i nerovnoměrnost rozložení. $K$ větším ztrátám dochází v oblastech mimo jádra volební podpory. Tato informace bude jistě důležitá pro vedení volební kampaně daných stran.

V následující části je vymezeno území stabilní volební podpory dle metody, kterou představili Jehlička a Sýkora (Voda 2015: 65). Ta spočívá v zobrazení těch území, kde se koncentruje $50 \%$ všech hlasů pro danou stranu. Data jsou zobrazena na úrovni obcí s rozšířenou působností (ORP); př́padná mapa na úrovni obcí by patrně nešla $v$ knize zřetelně zobrazit, na druhou stranu by přesněji či jemněji identifikovala toto území. Škoda, že mapy podle všeho nešlo uvést $\mathrm{v}$ barvě přes celou stránku, což by pro čtenáře bylo atraktivnější. Analýza de facto potvrdila známé závěry o územní podpoře tradičních stran. Proto pro čtenáře zřejmě nejzajímavější částí je ta věnovaná populistickým stranám, zejména Věcem veřejným (VV) a Úsvitu přímé demokracie. Škoda, že Petr Voda z analýzy vyloučil ANO2011, přestože do ní zařadil právě tyto dvě, jeho slovy „epizodni“", strany. Charakteristiky volební podpory ANO2011 by byly jistě zajímavé.

Vliv postkomunismu se patrně nejvíce projevuje na nestálosti volební podpory stran $\mathrm{v}$ čase, která je měřena pomocí Pearsonova korelačního koeficientu. Rakouské strany vykazují vysokou stabilitu při vysokých hodnotách koeficientu, naopak české strany mají obecně hodnotu nižší, která nadto u některých stran kolísá v čase. Nižší hodnota je i u tak tradičních stran, jako je KSČM a KDU-ČSL, což je na úrovni obcí možná způsobeno fragmentovanou strukturou, tedy i výslednou rozdílnou agregací výsledků. Koneckonců tento problém autor zmiňuje a snaží se s ním pracovat.

Analýza volební podpory je provedena na dvou úrovních agregace: na úrovni obcí a na úrovni „mikroregionů“. V českém př́padě se jedná o obvody obcí s rozšíŕenou působností $(205+15)$, v prrípadě Rakouska pak o politické okresy (120). Zde leží patrně jedna z hlavních překážek jakékoliv i budoucí komparativní analýzy. Česká obecní struktura je vysoce fragmentovaná snad s největším počtem obcí na počet obyvatel v Evropě. Zhruba $55 \%$ všech obcí tvoří nejmenší obce do 500 obyvatel. Tento fakt pak zcela jistě bude ovlivňovat následnou regresní analýzu, kdy každý prípad má stejnou váhu. To se zdánlivě netýká vyšší úrovně, tedy ORP, nicméně i mezi obvody pozorujeme značné rozdíly, co se týče jejich 
velikosti, respektive počtu obyvatel. Zatímco problémy se strukturou obcí byly akcentovány, problémy s ORP již nikoliv.

Jádro knihy tvoří ověření hypotéz vysvětlujících rozdíly ve volební podpoře na základě teorie konfliktních linií. $\mathrm{K}$ tomu slouží sada regresních modelů pro každou stranu zvlášt'. Vybrány byly čtyři konfliktní linie, které jsou v České republice dle autora př́tomny a ke kterým lze sehnat dostupná data: město venkov, církev - stát, vlastníci - pracující a materialismus - postmaterialismus. V rámci operacionalizace ke každé štěpící linii byla přiřazena sada indikátorů. Ty se mohou teoreticky překrývat, protože v praxi mohou indikovat více než jen jednu konfliktní linii. Jedná se o tradiční socioekonomické proměnné: podíl důchodců (věk), podíl VŠ vzdělaných obyvatel, podíl osob zaměstnaných v sekundéru, podíl nezaměstnaných, podíl podnikatelů a podíl rozvedených osob. Data autor čerpá ze sčítání lidu, přitom ale není dostatečně vysvětleno, proč nebylo možné použít data za př́slušný rok voleb a jaké by byly nevýhody tohoto postupu. Např́klad údaje za nezaměstnanost lze bez problémů získat, byt' se výpočet ČSÚ liší od MPSV, které navíc několikrát změnilo metodiku. Většinu dat lze od ČSÚ získat na úrovni obcí pro daný rok. Nicméně rozumím, že v př́padě snahy o co nejvyšší komparabilitu dat $\mathrm{v}$ čase a mezi dvěma zeměmi se použití dat v obou př́padech ze sčítání lidu jeví jako cesta nejmenšího odporu.

Mezi nezávisle proměnné byla do modelů vložena indikátorová proměnná kontrolující vliv velikosti obce. Před samotnou regresní analýzou byla provedena důkladná diagnostika proměnných. Velmi chválím i online apendix, kde jsou uvedeny grafy, tabulky a modely, které se již do textu nevešly a na které je odkazováno. $\mathrm{K}$ malému klopýtnutí došlo v př́padě kontroly multikolinearity, kdy se autor spokojil pouze s korelační maticí nezávisle proměnných. V korelační matici navíc chybí indikátorová proměnná velikost obce, která bude zcela jistě vysoce korelovaná s některými nezávisle proměnnými. Obecně u regresních modelů se socioekonomickými proměnnými je riziko multikolinearity vždy značné, proto by neměla chybět zmínka o hodnotách variačního inflačního faktoru. Hodnoty koeficientů pak mohou být nízké či dokonce „zkreslené“ právě kvưli multikolinearitě. V kombinaci s dummy proměnnými velikostí obce bych se nedivil, kdyby samotné hodnoty koeficientů byly výrazně ovlivněny výběrem proměnných $\mathrm{v}$ modelu. Zajímaly by mě tedy i modely bez kontroly velikosti obce, a zdali se neproměnily koeficienty u některých socioekonomických proměnných. Ty by mohly být rovněž prítomny $\mathrm{v}$ online apendixu podobně jako modely s vážením dle počtu obyvatel.

Pro jinou debatu by byla „poznámka k jedné obsesi“ - (ne)uvádění statistické významnosti. Přestože panuje zažité dogma, že v př́padě analýzy „celé populace“ nemá smysl u koeficientů uvádět „hvězdičky“, v některých prípadech je to teoreticky ospravedlnitelné. Řešením může být uvedení standardní chyby (místo standardizovaných koeficienti̊, které $\mathrm{v}$ tomto konkrétním př́padě nejsou př́liš užitečné). Standardní chyba nám neudává jen to, zdali lze usuzovat vlastnosti 
na základní soubor (což $\mathrm{v}$ tomto případě samozřejmě není potřeba a ani to není věcně správné), ale má i jiné vlastnosti. Čtenáři poskytne další informace ve změti čísel koeficientů u regresních modelů. Napŕíklad u regrese panel corrected standard errors by neuvedení korigovaných chyb postrádalo smysl využití této statistické metody. Tato poznámka není výtkou, spíše jen drobnou úvahou. Poslední připomínka $\mathrm{k}$ regresním modelům je ta, že tabulky mohly obsahovat i koeficient determinace pro snadné porovnání - jako v př́ipadě článku v časopise Communist and Postcommunist Studies (Voda, Pink 2015). ${ }^{3}$

Kniha Petra Vody naplnila ambiciózní cíl z části. Svého čtenáře si najde, a to především z řad studentů politologie. $\mathrm{Na}$ otázku „Jaká je role postkomunismu?" odpovídá bohužel stroze. $\mathrm{Na}$ druhou stranu obsahuje patrně nejdůkladnější analýzu volebních výsledků v prostoru na úrovni obcí vysvětlovanou socio-ekonomickými proměnnými, což je její hlavní devizou.

\section{Literatura}

Kostelecký, Tomáš, Renata Mikešová, Markéta Poláková, Daniel Čermák, Josef Bernard a Martin Šimon (2014): Koho voli Vaši sousedé? Prostorové vzorce volebního chování na území Ceska od roku 1920 do roku 2006, jejich zmèny a mo:̌né príriny. Praha: Sociologické nakladatelství SLON.

Kostelecký, Tomáš, Renata Mikešová, Markéta Poláková, Daniel Čermák, Josef Bernard a Martin Šimon (2015): Geografie výsledkư parlamentnich voleb: prostorové vzorce volebního chováni $v$ České republice 1992-2013. Praha: Sociologický ústav AV ČR.

Soukup, Petr a Ladislav Rabušic (2007): „Několik poznámek k jedné obsesi českých sociálních věd - statistické významnosti.“ Sociologický časopis/Czech Sociological Review 43(2): 379-395.

Voda, Petr a Michal Pink (2015): „Explanation of spatial differentiation of electoral results in the Czech Republic and Slovak Republic." Communist and Post-Communist Studies 48(4): 301-316. DOI: 10.2143/EP.20.1.2965124

\footnotetext{
${ }^{3}$ Je zajímavé, že čeští autoři statistickou významnost téměř nikdy neuvádějí, zatímco zahraniční ano. Článek Soukupa a Rabušice (2007) má evidentně v české „kvantitativní“ politologii obrovský ohlas.
} 